\title{
Cholecystokinin-8S-Induced Intracellular Calcium Signaling in Acutely Isolated Periaqueductal Gray Neurons of the Rat
}

\author{
Yu-Mi YAnG, ${ }^{a, b}$ Jun-Mo ChUng, ${ }^{b}$ and Hyewhon RHIM ${ }^{*, a}$ \\ ${ }^{a}$ Biomedical Research Center, Korea Institute of Science and Technology (KIST); Seoul 136-791, Korea: and ${ }^{b}$ Department \\ of Life Sciences, Ewha Womans University; Seoul 120-750, Korea. \\ Received August 30, 2006; accepted November 9, 2006
}

\begin{abstract}
Many behavior studies indicate that cholecystokinin (CCK) is related to nociception and anxiety/panic actions in the midbrain periaqueductal gray (PAG). We previously reported that a sulfated form of CCK octapeptide (CCK-8S) produced excitatory effects at both pre- and postsynaptic loci in PAG neurons using slice preparations and whole-cell patch-clamp recordings. Here, we further examined the detailed mechanism of CCK-8S in acutely isolated PAG neurons of the rat using fura-2-based imaging of intracellular $\mathrm{Ca}^{2+}$ concentration $\left(\left[\mathrm{Ca}^{2+}\right]_{i}\right)$ and whole-cell patch-clamp recordings. Application of $1 \mu_{\mathrm{M}} \mathrm{CCK}-8 \mathrm{~S}$ produced an increase of $\left[\mathrm{Ca}^{2+}\right]_{i}$, and its effect did not desensitize. This CCK-8S-induced $\left[\mathrm{Ca}^{2+}\right]_{i}$ increase was inhibited by the $\mathrm{CCK}_{2}$ receptor antagonist $\mathrm{L}-365260$ but not by the $\mathrm{CCK}_{1}$ receptor antagonist L-364718. In addition, the effect of CCK$8 S$ was eliminated by removing extracellular $\mathrm{Ca}^{2+}$, but not by an addition of the intracellular $\mathrm{Ca}^{2+}$ reuptake inhibitor thapsigargin. When simultaneous recordings of $\left[\mathrm{Ca}^{2+}\right]_{i}$ imaging and whole-cell patch-clamp were performed, CCK-8S-induced $\left[\mathrm{Ca}^{2+}\right]_{i}$ increase was significantly reduced at a membrane holding potential of $-60 \mathrm{mV}$ while CCK-8S-induced inward current was still observed. Current-voltage plots revealed that CCK-8S-induced inward current reversed near the equilibrium potential for $\mathrm{K}^{+}$ions with a decreased membrane conductance. However, CCK-8S produced a significant inhibition on high-voltage-activated $\mathrm{Ca}^{2+}$ channel currents. These results suggest that CCK-8S can excite PAG neurons by inhibiting $\mathrm{K}^{+}$channels, and $\mathrm{CCK}-8 \mathrm{~S}$-induced $\left[\mathrm{Ca}^{2+}\right]_{\mathrm{i}}$ increase occurs secondary to depolarization. The evidence presented here expands our understanding of cellular mechanisms for CCK-mediated anti-analgesic and anxiogenic actions in the PAG.
\end{abstract}

Key words cholecystokinin $(\mathrm{CCK})_{2}$ receptor; periaqueductal gray; $\mathrm{Ca}^{2+}$ channel; depolarization; fura-2; patch-clamp recording

The midbrain periaqueductal gray (PAG) plays a crucial role in the integration of an animal's behavioral, somatic, and autonomic responses to threat, stress, and pain. ${ }^{1,2)}$ In particular, the PAG is a major site for modulation of nociception and a part of descending antinociceptive systems that relay via the rostral ventromedial medulla (RVM) to the spinal cord. ${ }^{3,4)}$ In addition, stimulation of dorsal PAG in several species produced defense reaction, anxiety, and fear, and lesions of the PAG produced anxiolytic effect. ${ }^{5,6)}$ Cholecystokinin (CCK) is a bioactive peptide that functions as a gastrointestinal hormone and a neuropeptide in both the peripheral and central nervous systems. As one of the most abundant neuropeptides in the brain, CCK has also been known to influence a variety of behaviors such as satiety, nociception, and anxiety/panic action in the brain. ${ }^{7-9)}$ Immunocytochemical studies have demonstrated that CCK is a major neurotransmitter or modulator in the PAG, and CCK receptors are heterogeneously distributed within the PAG. ${ }^{10,11)}$ Microinjection of CCK or CCK receptor antagonists into the PAG antagonized or potentiated the acute antinociceptive effect of microinjected morphine, respectively. ${ }^{12-15)}$ In addition, Netto et al. ${ }^{16)}$ reported that microinjection of CCK into the PAG produced an anxiogenic effect through $\mathrm{CCK}_{2}$ receptors using an animal model of anxiety. Based on these behavioral studies, the PAG could be a key site of anti-analgesic and anxiogenic actions of CCK, and it is possible that these effects of CCK are mediated through an alteration of neuronal activities in the PAG.

CCK exerts its physiological effects via two subtypes of receptors, $\mathrm{CCK}_{1}$ and $\mathrm{CCK}_{2}$ receptors. ${ }^{8,9)}$ Both $\mathrm{CCK}$ receptors belong to a superfamily of $\mathrm{G}$ protein-coupled receptors (GPCR) ${ }^{7,17,18)}$ Direct coupling of $\mathrm{CCK}_{1}$ and $\mathrm{CCK}_{2}$ receptors onto $\mathrm{G} \alpha_{\mathrm{q}}$ to activate phospholipase C (PLC) and cause intra- cellular $\mathrm{Ca}^{2+}$ signaling has been well demonstrated in pancreatic acinar cells ${ }^{19-21)}$ and several cell lines. ${ }^{22-24)}$ However, this effect is not clearly demonstrated in the central nervous system (CNS). We recently reported that CCK excited PAG neurons at both pre- and postsynaptic loci via the activation of $\mathrm{CCK}_{2}$ receptors using slice preparations and whole-cell patch-clamp recordings. ${ }^{25}$ ) Therefore, in order to examine whether CCK could modulate intracellular $\mathrm{Ca}^{2+}$ mobilizations in PAG neurons, we examined the effects of a sulfated form of CCK octapeptide (CCK-8S) using fura-2-based intracellular $\mathrm{Ca}^{2+}$ concentration $\left(\left[\mathrm{Ca}^{2+}\right]_{\mathrm{i}}\right)$ and whole-cell patch-clamp recordings in acutely isolated PAG neurons of the rat.

\section{MATERIALS AND METHODS}

Acute Isolation of PAG Neurons PAG neurons with synaptic boutons were acutely isolated using the technique modified from Hahm et al. ${ }^{26)}$ Briefly, 12 to 21-d-old SpragueDawley rats were anesthetized and decapitated in accordance with the NIH Guide for the Care of Use of Laboratory Animals (revised 1996). The brains were quickly removed and immersed in an ice-cold artificial cerebrospinal fluid (ACSF) containing (in mM): $126 \mathrm{NaCl}, 26.2 \mathrm{NaHCO}_{3}, 2.5 \mathrm{KCl}, 1.25$ $\mathrm{NaH}_{2} \mathrm{PO}_{4}, 2.5 \mathrm{CaCl}_{2}, 1.5 \mathrm{MgSO}_{4}, 10$ glucose, and 10 sucrose gassed with $95 \% \mathrm{O}_{2}$ and $5 \% \mathrm{CO}_{2}$. Transverse midbrain slices ( $400 \mu \mathrm{m}$ thick) containing the PAG were cut with the use of a Vibratome tissue slicer. Slices were preincubated in ACSF that had been well saturated with $95 \% \mathrm{O}_{2}$ and $5 \% \mathrm{CO}_{2}$ at $32{ }^{\circ} \mathrm{C}$ for $c a .1 \mathrm{~h}$ before a mechanical dissociation. For the mechanical isolation of PAG neurons, slices were transferred into a 35-mm culture dish (Primaria 3801, Becton Dickinson, 
NJ, U.S.A.), and a fire-polished glass pipette was lightly touched onto the dorsolateral region of the PAG with $1-$ $2 \mathrm{~mm}$ of working distance. The tip of the glass pipette was horizontally vibrated at ca. $20-50 \mathrm{~Hz}$ for $c a .2 \mathrm{~min}$. Slices were removed, and the mechanically dissociated neurons were allowed to settle for $20 \mathrm{~min}$ for intracellular $\mathrm{Ca}^{2+}$ imaging and electrophysiological studies.

Intracellular $\mathrm{Ca}^{2+}$ Imaging The acetoxymethyl-ester form of fura-2 (fura-2/AM) was used as the fluorescent $\mathrm{Ca}^{2+}$ indicator. Cells were incubated for $40-60 \mathrm{~min}$ at room temperature with $5 \mu \mathrm{M}$ fura-2/AM and $0.001 \%$ pluronic F-127 in a HEPES-buffered solution composed of (in mM): $150 \mathrm{NaCl}$, $5 \mathrm{KCl}, 2 \mathrm{CaCl}_{2}, 1 \mathrm{MgCl}_{2}, 10$ glucose, and 10 HEPES, $\mathrm{pH}$ adjusted to 7.4 with $\mathrm{NaOH}$. Cells were illuminated using a xenon arc lamp, and excitation wavelengths $(340,380 \mathrm{~nm})$ were selected by a computer-controlled filter wheel (Sutter Instruments, CA, U.S.A.). Emitter fluorescence was reflected through a $515 \mathrm{~nm}$ long-pass filter to a frame transfer cooled CCD camera, then the ratios of emitted fluorescence were calculated using a digital fluorescence analyzer and converted to intracellular free $\mathrm{Ca}^{2+}$ concentration $\left(\left[\mathrm{Ca}^{2+}\right]_{\mathrm{i}}\right)$ using the Eq. 1

$$
\left[\mathrm{Ca}^{2+}\right]_{\mathrm{i}}=K_{\mathrm{d}} \beta\left(R-R_{\text {min }}\right) /\left(R_{\text {max }}-R\right)
$$

where $K_{\mathrm{d}}$ is the dissociation constant for fura-2, $R_{\min }$ is the $340 / 380$ fluorescence ratio in the presence of zero $\mathrm{Ca}^{2+}, R_{\max }$ is the ratio in the presence of saturating concentrations of $\mathrm{Ca}^{2+}$, and $\beta$ is the ratio of fluorescence during $380-\mathrm{mm}$ excitation at zero and saturating $\mathrm{Ca}^{2+}$ concentrations. All imaging data were collected and analyzed using Universal Imaging software (West Chester, PA, U.S.A.). Saline with $50 \mathrm{~mm}$ $\mathrm{KCl}$ was made by replacing an equivalent amount of $\mathrm{NaCl}$.

Electrophysiological Recordings Electrophysiological recordings were achieved using whole-cell patch-clamp techniques at room temperature $\left(22-25^{\circ} \mathrm{C}\right)$. For $\mathrm{Ca}^{2+}$ currents recordings, patch electrodes with resistance of $3-4 \mathrm{M} \Omega$ were filled with an internal solution containing (in $\mathrm{mm}$ ): 110 CsCl, 5 Mg-ATP, $0.2 \mathrm{Na}$-GTP, 10 EGTA, $2 \mathrm{CaCl}_{2}$, and 10 HEPES ( $\mathrm{pH} \mathrm{7.3).} \mathrm{The} \mathrm{external} \mathrm{solution} \mathrm{contained} \mathrm{(in} \mathrm{mm}$ ): 140 TEA-Cl, $4 \mathrm{BaCl}_{2}, 2.5 \mathrm{CsCl}, 10$ HEPES, and 10 glucose, $\mathrm{pH}$-adjusted to 7.4 with TEA-OH. High-voltage-activated (HVA) $\mathrm{Ca}^{2+}$ currents were evoked every $15 \mathrm{~s}$ by a $200 \mathrm{~ms}$ depolarizing voltage step from -60 to $0 \mathrm{mV}$. For recordings of CCK-induced inward currents, the nystatin perforated patchclamp method was employed at a holding potential $\left(V_{\mathrm{h}}\right)$ of $-60 \mathrm{mV}$. Patch electrodes were filled with an internal solution containing (in $\mathrm{mm}$ ): $120 \mathrm{~K}$-gluconate, $20 \mathrm{NaCl}, 2$ $\mathrm{MgCl}_{2}$, and 10 HEPES (pH 7.4). Nystatin was prepared as a stock solution $(25 \mathrm{mg} / \mathrm{ml})$ in dimethylsulphoxide (DMSO), diluted to a concentration of $250 \mu \mathrm{g} / \mathrm{ml}$ using the internal solution, and back-filled into the pipette after the tip of the pipette was initially filled with the nystatin-free solution. The external solution contained (in $\mathrm{mm}$ ): $150 \mathrm{NaCl}, 2.5 \mathrm{KCl}, 1$ $\mathrm{MgCl}_{2} 2 \mathrm{CaCl}_{2}, 10 \mathrm{HEPES}$, and 10 glucose. All experiment recordings were obtained with an EPC-9 amplifier (filtered at $10 \mathrm{kHz}$ ) and digitized at a sampling frequency of $1 \mathrm{kHz}$.

Data Analysis All data were analyzed using Pulse/Pulsefit (HEKA, Germany) and Prism (GraphPad Software Inc., CA, U.S.A.) software. All data were expressed as the mean \pm S.E. Statistical significance was determined by using a paired or unpaired Student's $t$-test. Statistical significance was set at $p<0.05$ level.

Drugs Stock solutions of all drugs were made in distilled water, except CCK receptor antagonists (made in DMSO). These were diluted to a final concentration using ACSF and applied to the perfusate. Cholecystokinin octapeptide (CCK-8S) was purchased from Tocris Cookson (Bristol, U.K.); fura-2/AM from Molecular probes (OR, U.S.A.); L364718 and L-365260 were a gift from ML Laboratories (Warrington, U.K.). All other chemicals were purchased from Sigma (MO, U.S.A.).

\section{RESULTS AND DISCUSSION}

CCK-8S Increases $\left[\mathrm{Ca}^{2+}\right]_{i}$ in Acutely Isolated PAG Neurons We previously reported that CCK produces excitatory effects at both pre- and postsynaptic loci in most PAG neurons tested using slice preparations and whole-cell patchclamp recordings. ${ }^{25}$ These results suggest that CCK is a main neurotransmitter to modulate neuronal activities in the PAG and also indicate possible CCK-mediated modulation on intracellular $\mathrm{Ca}^{2+}$ signaling via $\mathrm{G} \alpha /$ PLC pathways in the CNS as has occurred in pancreatic cells ${ }^{19-21)}$ and several cell lines. $^{22-24)}$ In the present study, we examined the effects of CCK on $\left[\mathrm{Ca}^{2+}\right]_{\mathrm{i}}$ in acutely dissociated PAG neurons using a sulfated form of CCK octapeptide (CCK-8S), the most abundant and endogenously active form of CCK in the brain. Application of $1 \mu \mathrm{M}$ CCK-8S induced an increase of $\left[\mathrm{Ca}^{2+}\right]_{\mathrm{i}}$ in most PAG neurons tested (Fig. 1A). This CCK-8S-induced response peaked within $30-50 \mathrm{~s}$ after the drug application and returned to the basal level about $2-5 \mathrm{~min}$ after washout. We examined more than 160 PAG neurons $(n=168)$ and found that ca. $91 \%$ cell of them produced an increase of $\left[\mathrm{Ca}^{2+}\right]_{\mathrm{i}}$ by CCK-8S. The mean increase of $\left[\mathrm{Ca}^{2+}\right]_{\mathrm{i}}$ was $151.3 \pm 6.3 \mathrm{~nm}$ by $1 \mu \mathrm{M}$ CCK-8S $(n=153)$. In order to confirm that the response of CCK-8S was recorded from PAG neurons and not non-neuronal cells such as glia, we checked the responsiveness of a high concentration of $\mathrm{KCl}(50 \mathrm{~mm})$ to cells at the end of each experiment. In a separate set of experiments, we observed that CCK-8S-induced $\left[\mathrm{Ca}^{2+}\right]_{\mathrm{i}}$ increase was reproducible and occurred in a concentration-dependent manner. The degree of CCK-8S-induced $\left[\mathrm{Ca}^{2+}\right]_{\mathrm{i}}$ increase was not significantly changed by a second application of the drug $(103.3 \pm 3.8 \%$ of first application, $n=14$, Fig. 1B). This result suggests that CCK-8S-induced $\left[\mathrm{Ca}^{2+}\right]_{\mathrm{i}}$ increase does not desensitize. As shown in Fig. 1C, application of CCK-8S between $1 \mathrm{~nm}$ to $10 \mu \mathrm{M}$ produced an increase of $\left[\mathrm{Ca}^{2+}\right]_{\mathrm{i}}$ in a concentration-dependent manner with the $\mathrm{EC}_{50}$ value of $156.0 \mathrm{~nm}$.

To evaluate which of the subtypes of CCK receptors is involved in CCK-8S-induced $\left[\mathrm{Ca}^{2+}\right]_{\mathrm{i}}$ increase, two selective $\mathrm{CCK}$ receptor antagonists, the $\mathrm{CCK}_{2}$ receptor antagonist L365260 and the $\mathrm{CCK}_{1}$ receptor antagonist L-364718, were used. As shown in Fig. 1D, CCK-8S-induced $\left[\mathrm{Ca}^{2+}\right]_{\mathrm{i}}$ increase was significantly reduced by the $\mathrm{CCK}_{2}$ receptor antagonist, L-365260 (56.2 $\pm 12.1 \%$ of control, $n=9, p<0.01)$ while it was not affected by the $\mathrm{CCK}_{1}$ receptor antagonist L-364718 $(89.8 \pm 4.9 \%, n=8)$ at the concentration of 100 nM. Furthermore, the blockade of L-365260 on CCK-8S-induced $\left[\mathrm{Ca}^{2+}\right]_{\mathrm{i}}$ increase occurred in a concentration-dependent manner. The mean percentage values by $1 \mu \mathrm{M}$ and $10 \mu \mathrm{M}$ L-365260 were $34.7 \pm 9.6 \%(n=8)$ and $23.0 \pm 4.6 \%$ of control $(n=18)$, re- 
A

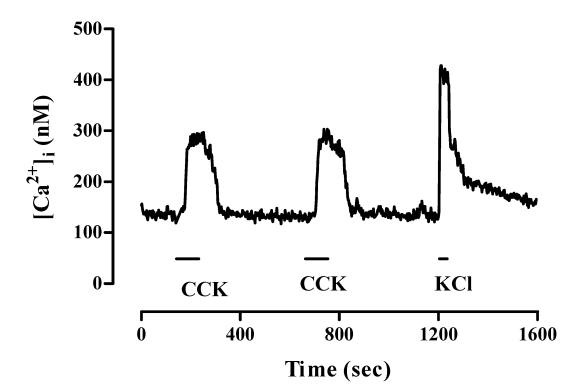

C

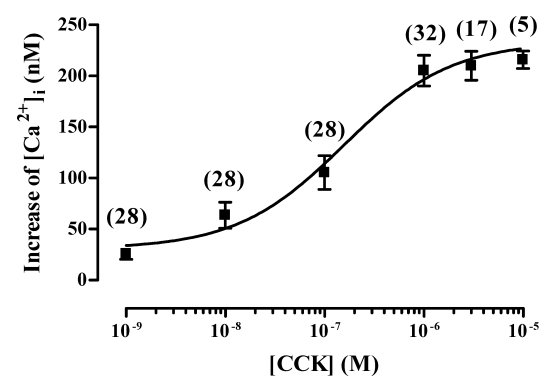

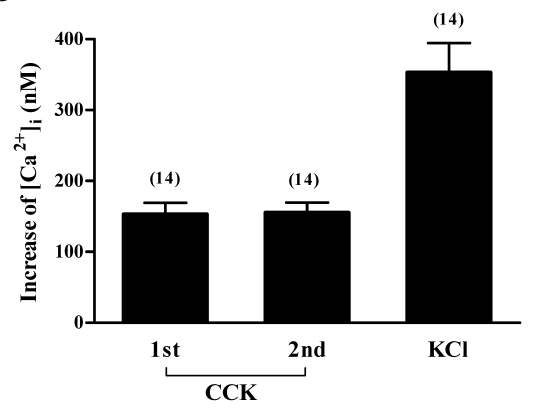

D



Fig. 1. CCK-8S-Induced $\left[\mathrm{Ca}^{2+}\right]_{\mathrm{i}}$ Increase in Acutely Isolated PAG Neurons of the Rat

(A) Application of CCK- $8 \mathrm{~S}(1 \mu \mathrm{M})$ for $1.5 \mathrm{~min}$ repeatedly produced an increase of $\left[\mathrm{Ca}^{2+}\right]_{\mathrm{i}}$ in an acutely isolated PAG neuron. At the end of each experiment, a high concentration of $\mathrm{KCl}(50 \mathrm{~mm}$ ) was applied to a cell for $30 \mathrm{~s}$ in order to confirm the cell tested is a PAG neuron, not a non-neuronal cell. (B) Pooled results illustrating the mean increases of $\left[\mathrm{Ca}^{2+}\right]_{\mathrm{i}}$ by $1 \mathrm{st}$, 2nd application of $1 \mu \mathrm{M}$ CCK-8S, or $50 \mathrm{~mm} \mathrm{KCl}$. (C) Concentration-dependent curve for CCK-8S-induced $\left[\mathrm{Ca}^{2+}\right]_{\mathrm{i}}$ increase. The change of $\left[\mathrm{Ca}^{2+}\right]_{\mathrm{i}}$ is plotted as a function of CCK-8S concentration. The solid line connecting the points represents the computer fit of the data to a logistic equation, $y=I_{\min }+\left(I_{\max }-I_{\min }\right) /\left(1+10^{(\mathrm{LogECC} 50-X)}\right)$, where $I_{\min }$ and $I_{\max }$ are the minimum and maximum $\left[\mathrm{Ca}^{2+}\right]_{\text {; }}$, respectively, $X$ is the logarithm of CCK-8S concentration. The $\mathrm{EC}_{50}$ value of CCK-8S on increasing $\left[\mathrm{Ca}^{2+}\right]_{\mathrm{i}}$ is $156.0 \mathrm{~nm}$. $(\mathrm{D})$


tagonist L-365260 but not by the $\mathrm{CCK}_{1}$ receptor antagonist L-364718. Each antagonist was used at $100 \mathrm{~nm}$. Inset, concentration-dependent blockade of L-365260 on CCK-8S-induced $\left[\mathrm{Ca}^{2+}\right]_{\mathrm{i}}$ increase from $100 \mathrm{~nm}$ to $10 \mu \mathrm{M}$. *** $p<0.01, * * * p<0.001$.

spectively. These results suggest that $\mathrm{CCK}-8 \mathrm{~S}$ produces an increase of $\left[\mathrm{Ca}^{2+}\right]_{\mathrm{i}}$ via the activation of $\mathrm{CCK}_{2}$ receptors in the PAG.

The Role of Extracellular $\mathrm{Ca}^{2+}$ in CCK-8S-Induced $\left[\mathrm{Ca}^{2+}\right]_{\mathrm{i}}$ Increase To determine sources of $\left[\mathrm{Ca}^{2+}\right]_{\mathrm{i}}$ increased by CCK-8S, the experiments with $\mathrm{Ca}^{2+}$-free environment or the intracellular $\mathrm{Ca}^{2+}$ reuptake inhibitor thapsigargin were performed. First, when $1 \mu_{\mathrm{M}} \mathrm{CCK}-8 \mathrm{~S}$ was applied in $\mathrm{Ca}^{2+}$ free HEPES buffered solution, CCK-8S-induced $\left[\mathrm{Ca}^{2+}\right]_{\mathrm{i}}$ in-

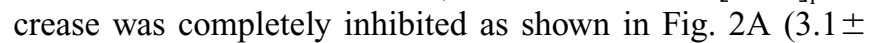
$2.6 \%$ of control, $n=27, p<0.001)$. In contrast, pre-treatment with thapsigargin $(2 \mu \mathrm{M}, 5 \mathrm{~min})$ in order to deplete intracellular $\mathrm{Ca}^{2+}$ stores did not significantly affect CCK-8S-induced $\left[\mathrm{Ca}^{2+}\right]_{\mathrm{i}}$ increase $(101.5 \pm 13.2 \%, n=12$, Fig. 2B). These results suggest that the main source for CCK-8S-induced $\left[\mathrm{Ca}^{2+}\right]_{\mathrm{i}}$ increase is influx of $\mathrm{Ca}^{2+}$ from the extracellular space and exclude any involvement of intracellular $\mathrm{Ca}^{2+}$ stores in the PAG. However, $\mathrm{CCK}_{2}$ receptors have been known to activate $\mathrm{PLC}$, thereby triggering an increase in inositol 1,4,5trisphosphate $\left(\mathrm{IP}_{3}\right)$ production via a $\mathrm{G} \alpha_{\mathrm{q}}$ protein in pancreatic cells and clonal cell lines. ${ }^{19-22,24)}$ To test any possibility of dysfunction in the coupling system between GPCRs and $\mathrm{PLC} / \mathrm{IP}_{3}$ pathways due to isolation processes of PAG neurons, we examined the effect of substance $\mathrm{P}$ (SP) which is also bound to $\mathrm{G} \alpha_{\mathrm{q}}$ protein-coupled SP receptors. As shown in Fig. 2C, application of $1 \mu \mathrm{M}$ SP induced an increase of $\left[\mathrm{Ca}^{2+}\right]_{\mathrm{i}}$ in PAG neurons $(131.9 \pm 12.9 \mathrm{nM}, n=41)$ and still produced an increase of $\left[\mathrm{Ca}^{2+}\right]_{\mathrm{i}}$ in $\mathrm{Ca}^{2+}$-free HEPES buffered solution $(89.3 \pm 6.0 \%$ of control, $n=12)$ in contrast to CCK8S. Furthermore, SP-induced $\left[\mathrm{Ca}^{2+}\right]_{\mathrm{i}}$ increase was com- pletely inhibited by the PLC inhibitor U73122 $(10 \mu \mathrm{M}$, $4.9 \pm 1.5 \%$ of control, $n=25, p<0.001$, Fig. 2D). These results suggest that the coupling system between $\mathrm{G} \alpha_{\mathrm{q}}$-proteincoupled receptors and PLC/IP 3 pathways is properly operated in the acutely isolated PAG neurons which we used, and CCK-8S produces $\left[\mathrm{Ca}^{2+}\right]_{\mathrm{i}}$ increase via influx of $\mathrm{Ca}^{2+}$ from the extracellular space, but not intracellular $\mathrm{Ca}^{2+}$ stores coupled to PLC-dependent pathway in the PAG.

Simultaneous Recordings of CCK-8S-Induced $\left[\mathrm{Ca}^{2+}\right]_{i}$ Increase and Membrane Currents To examine whether CCK-8S-induced $\left[\mathrm{Ca}^{2+}\right]_{\mathrm{i}}$ increase is caused by a membrane depolarization which we observed in our previous study recorded in midbrain slice preparations, ${ }^{25}$ ) simultaneous recordings of $\left[\mathrm{Ca}^{2+}\right]_{\mathrm{i}}$ imaging and whole-cell patch-clamp were performed in acutely isolated PAG neurons. The PAG neurons subjected to the measurement of $\left[\mathrm{Ca}^{2+}\right]_{\mathrm{i}}$ imaging were recorded at a holding potential $\left(V_{\mathrm{h}}\right)$ of $-60 \mathrm{mV}$ using perforated whole-cell patch-clamp techniques in the presence of the $\mathrm{Na}^{+}$channel blocker tetrodotoxin (TTX, 300 nM). Under this condition, $1 \mu \mathrm{M}$ CCK-8S produced an inward current $(12.4 \pm 3.8 \mathrm{pA}, n=7)$, which is comparable with that obtained by sole patch-clamp recording $(17.8 \pm 1.4 \mathrm{pA}, n=13)$. However, CCK-8S-induced $\left[\mathrm{Ca}^{2+}\right]_{\mathrm{i}}$ increase was significantly reduced by voltage-clamp recordings when membrane potential was clamped at $-60 \mathrm{mV}$ (Fig. 3A). The mean increases of $\left[\mathrm{Ca}^{2+}\right]_{\mathrm{i}}$ without and with voltage-clamp recordings were $151.3 \pm 6.3 \mathrm{~nm}$ and $45.8 \pm 6.3 \mathrm{~nm}$, respectively $(n=7, p<0.01$, Fig. 3B). These results suggest that CCK-8S-induced $\left[\mathrm{Ca}^{2+}\right]_{\mathrm{i}}$ increase occurred secondary to a membrane depolarization in acutely isolated PAG neurons. What types of ion channels are 
A
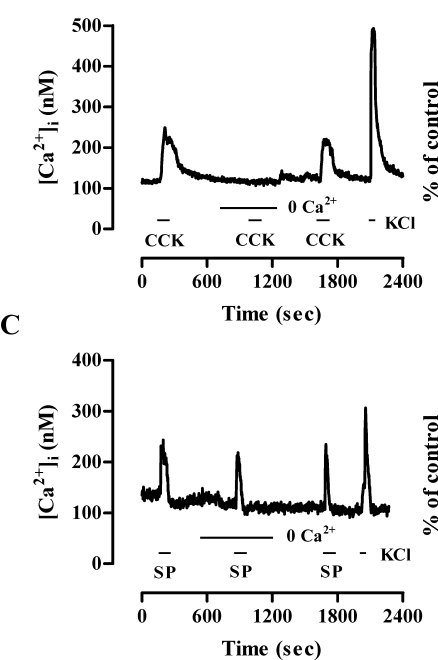
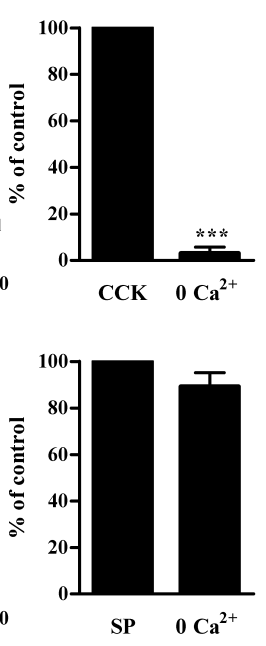

B
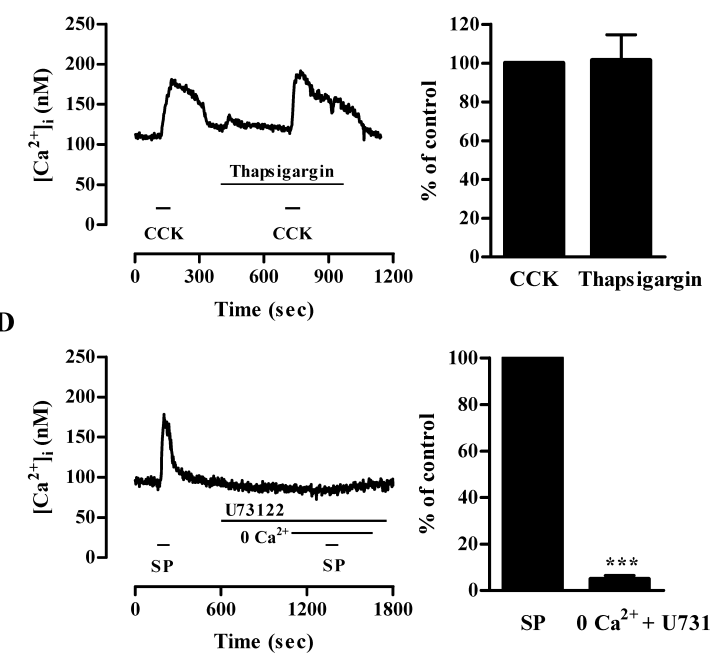

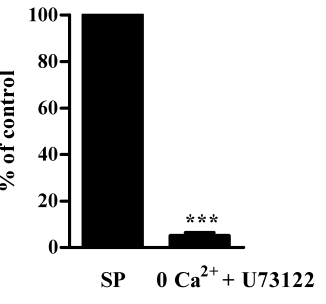

Fig. 2. The Role of Extracellular $\mathrm{Ca}^{2+}$ on CCK-8S-Induced $\left[\mathrm{Ca}^{2+}\right]_{\mathrm{i}}$ Increase

(A) CCK-8S-induced $\left[\mathrm{Ca}^{2+}\right]_{\mathrm{i}}$ increase was significantly inhibited in $\mathrm{Ca}^{2+}$-free HEPES buffered solution $\left(0 \mathrm{Ca}^{2+}, 3.1 \pm 2.6 \%\right.$ of control, $\left.n=27\right)$. (B) shows that CCK-8S-induced effect was not inhibited by pre-treatment ( $5 \mathrm{~min}$ ) with the intracellular $\mathrm{Ca}^{2+}$ reuptake inhibitor thapsigargin $(2 \mu \mathrm{M}, 101.5 \pm 13.2 \%, n=12)$. (C) and (D) Application of substance $\mathrm{P}$ $(\mathrm{SP}, 1 \mu \mathrm{M})$ also induced an increase of $\left[\mathrm{Ca}^{2+}\right]_{\mathrm{i}}$ in an acutely isolated PAG neuron. This SP-induced $\left[\mathrm{Ca}^{2+}\right]_{\mathrm{i}}$ increase was still observed in $\mathrm{Ca}^{2+}$-free bath solution $(89.3 \pm 6.0 \%$ of control, $n=12)$ but completely inhibited by treatment with the phospholipase C (PLC) inhibitor U73122 $(10 \mu \mathrm{M}, 4.9 \pm 1.5 \%$ of control, $n=25)$. *** $p<0.001$.

A

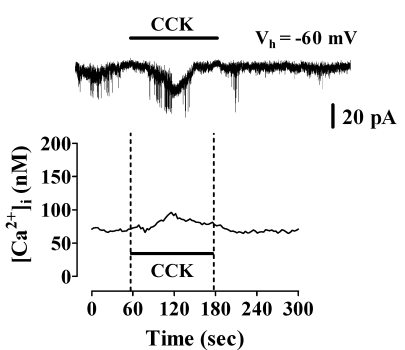

B

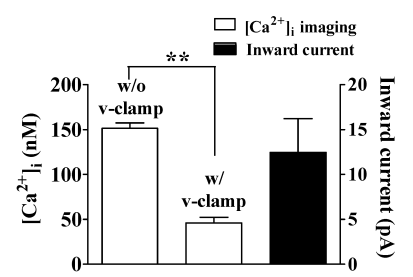

C

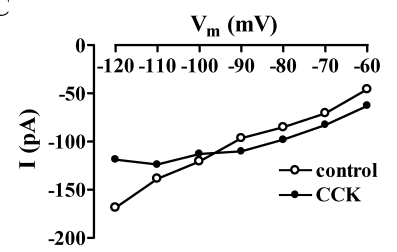

D



$\mathbf{E}$



F

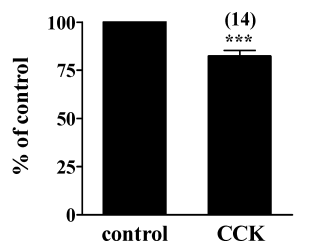

Fig. 3. Effects of CCK-8S on Membrane Holding Currents and $\mathrm{Ca}^{2+}$ Channels under Voltage-Clamp Conditions

(A) The simultaneous recording of $1 \mu \mathrm{M}$ CCK-8S-induced $\left[\mathrm{Ca}^{2+}\right]_{\mathrm{i}}$ increase and membrane inward currents. Membrane currents of a neuron subjected to $\left[\mathrm{Ca}{ }^{2+}\right]_{\mathrm{i}}$ imaging were simultaneously recorded using perforated whole-cell patch-clamp techniques. (B) The mean values of CCK-8S-induced [Ca $\left.{ }^{2+}\right]_{\mathrm{i}}$ increase without and with voltage-clamp recordings were $151.3 \pm 6.3 \mathrm{~nm}$ and $56.8 \pm 12.3 \mathrm{~nm}(n=7)$, respectively. The mean amplitude of CCK-8S-induced inward current was $12.4 \pm 3.8 \mathrm{pA}(n=7)$ when membrane potential was clamped at $-60 \mathrm{mV}$. (C) The steady-state current-voltage $(I-V)$ relationship prior to $(\bigcirc)$ and in the presence of $1 \mu \mathrm{M}$ CCK-8S $(O)$ for an acutely isolated PAG neuron. The mean value of $E_{\text {rev }}$ is $-95.7 \pm 3.2 \mathrm{mV}(n=6)$ when $2.5 \mathrm{~mm}$ extracellular $\mathrm{K}^{+}$concentration was used. Cells were held at $V_{\mathrm{h}}$ of $-60 \mathrm{mV}$ and given square pulses from -130 to $-60 \mathrm{mV}$ with $10-\mathrm{mV}$ steps. (D) The peak $I-V$ relationship for whole-cell $\mathrm{Ca}^{2+}$ currents prior to $(\mathrm{O})$ and in the presence of $1 \mu \mathrm{M} C \mathrm{CK}-8 \mathrm{~S}(\bullet)$ in an acutely isolated PAG neuron. Ca ${ }^{2+}$ currents were evoked at $V_{\mathrm{h}}$ of $-60 \mathrm{mV}$ by depolarization to the test potentials from -70 to $+30 \mathrm{mV}$ with $10-\mathrm{mV}$ steps. CCK- $8 \mathrm{~S}$ moderately inhibited high-voltage-activated (HVA) Ca ${ }^{2+}$ currents without changing low-voltage-activated (LVA) $\mathrm{Ca}^{2+}$ currents. (E) $1 \mu \mathrm{M}$ CCK-8S partially reduced $\mathrm{HVA} \mathrm{Ca}^{2+}$ currents. $\mathrm{HVA} \mathrm{Ca}^{2+}$ currents were evoked every $15 \mathrm{~s}$ by a $200 \mathrm{~ms}$ depolarizing voltage step from -60 to $0 \mathrm{mV}$ and completely blocked by $100 \mu \mathrm{M} \mathrm{Cd}{ }^{2+}$. (F) Illustrates the summarized results of CCK-8S on $\mathrm{HVA}$ Ca ${ }^{2+}$ currents. CCK-8S significantly inhibited HVA $\mathrm{Ca}^{2+}$ currents from 14 cells tested $(82.2 \pm 3.1 \%$ of control). $* * * p<0.001$.

involved in CCK-8S-induced inward currents in order to modulate intracellular $\mathrm{Ca}^{2+}$ signaling? As shown in Fig. 3C, the current-voltage $(I-V)$ relationship with or without CCK-
$8 \mathrm{~S}$ indicated that CCK-8S caused a decrease in the wholecell slope conductance with a reversal potential $\left(E_{\text {rev }}\right)$ of $-95.7 \pm 3.2 \mathrm{mV}(n=6)$, which was similar to the $E_{\mathrm{rev}}$ of $\mathrm{K}^{+}$ 
ion predicted by the Nernst equation when an extracellular $\mathrm{K}^{+}$concentration is $2.5 \mathrm{~mm}$ (predicted $E_{\mathrm{rev}}=-97.8 \mathrm{mV}$ ). All together, these results suggest that CCK-8S induced an increase of $\left[\mathrm{Ca}^{2+}\right]_{\mathrm{i}}$ by $\mathrm{K}^{+}$channel-mediated depolarization of membrane potentials in acutely isolated PAG neurons.

Inhibition of $\mathrm{Ca}^{2+}$ Currents by CCK-8S From the involvement of both $\mathrm{K}^{+}$channel-mediated depolarization and extracellular $\mathrm{Ca}^{2+}$, we next directly investigated any involvement of voltage-dependent $\mathrm{Ca}^{2+}$ channels in CCK-8S-induced $\left[\mathrm{Ca}^{2+}\right]_{\mathrm{i}}$ increase. When whole-cell $\mathrm{Ca}^{2+}$ currents were acquired for $200 \mathrm{~ms}$ depolarized pulses from -70 to +30 $\mathrm{mV}$ at $V_{\mathrm{h}}$ of $-60 \mathrm{mV}$ with $10-\mathrm{mV}$ voltage increments, the $I-$ $V$ relationship was examined. Figure 3D illustrates the peak $I-V$ relation for a neuron in the absence and presence of $1 \mu \mathrm{M}$ CCK-8S. CCK-8S moderately inhibited high-voltage-activated (HVA) $\mathrm{Ca}^{2+}$ currents with no significant change on low-voltage-activated (LVA) $\mathrm{Ca}^{2+}$ currents which activated around $-30 \mathrm{mV}$. When the effect of CCK-8S was further examined on HVA $\mathrm{Ca}^{2+}$ currents which were evoked every $15 \mathrm{~s}$ by a $200 \mathrm{~ms}$ depolarizing voltage step from -60 to $0 \mathrm{mV}, 1$ $\mu \mathrm{M}$ CCK-8S partially inhibited HVA $\mathrm{Ca}^{2+}$ currents (Fig. 3E), and this effect was reversible (data not shown). Figure $3 \mathrm{~F}$ illustrates the pooled results showing the effects of CCK-8S on $\mathrm{HVA} \mathrm{Ca}{ }^{2+}$ currents from 14 cells tested. Although the degree of inhibition was small, CCK-8S produced a significant inhibition on $\mathrm{HVA} \mathrm{Ca}^{2+}$ currents $(82.2 \pm 3.1 \%$ of control, $n=$ $14, p<0.001)$. Under this condition, application of $100 \mu \mathrm{M}$ $\mathrm{CdCl}_{2}$ abolished the inward currents elicited by a $200 \mathrm{~ms}$ depolarization pulse to $0 \mathrm{mV}$, indicating most of the inward currents are HVA $\mathrm{Ca}^{2+}$ currents. Taken together, these results suggest that CCK-8S partially, but significantly, inhibited HVA $\mathrm{Ca}^{2+}$ currents in the PAG.

In our previous study, we examined the actions of CCK-8S at the cellular level and identified two prominent effects in rat PAG neurons using slice preparations; CCK can excite PAG neurons at both pre- and postsynaptic loci via the activation of $\mathrm{CCK}_{2}$ receptors. ${ }^{25)}$ Specifically, CCK-8S produced a membrane depolarization or an inward current accompanied by increased spontaneous synaptic activities and increased the frequency of miniature excitatory postsynaptic currents (mEPSCs). Based on these observations, we further examined whether CCK-8S could modulate intracellular $\mathrm{Ca}^{2+}$ signaling in the PAG as reported in other systems. In acutely isolated PAG neurons using fura-2-based $\left[\mathrm{Ca}^{2+}\right]_{\mathrm{i}} \mathrm{im}-$ aging and whole-cell patch-clamp recordings, the main findings of the present study are as follows: (1) CCK-8S produces an increase of $\left[\mathrm{Ca}^{2+}\right]_{\mathrm{i}}$ via the activation of $\mathrm{CCK}_{2}$ receptors. (2) The sources of $\left[\mathrm{Ca}^{2+}\right]_{\mathrm{i}}$ increased by CCK-8S are not $\mathrm{G} \alpha / \mathrm{PLC}$-mediated intracellular $\mathrm{Ca}^{2+}$ stores, but influx of $\mathrm{Ca}^{2+}$ from the extracellular space. (3) CCK-8S-induced $\left[\mathrm{Ca}^{2+}\right]_{\mathrm{i}}$ increase is significantly reduced under voltageclamp conditions. (4) CCK-8S partially, but significantly, inhibits $\mathrm{HVA} \mathrm{Ca}^{2+}$ currents.

Intracellular $\mathrm{Ca}^{2+}$ plays an important role in $\mathrm{Ca}^{2+}$-regulated neuronal functions such as membrane excitability, neurotransmitter release, and synaptic plasticity. ${ }^{27,28)}$ It is not only controlled by the release of $\mathrm{Ca}^{2+}$ from intracellular stores, but also by influx of $\mathrm{Ca}^{2+}$ into the cell through voltage-dependent $\mathrm{Ca}^{2+}$ channels. Although it has been well established that pancreatic cholecystokinin (CCK) receptors induce an increase of $\left[\mathrm{Ca}^{2+}\right]_{\mathrm{i}}$ from the release of intracellular
$\mathrm{Ca}^{2+}$ stores via $\mathrm{G}_{\mathrm{q}} / \mathrm{PLC} / \mathrm{IP}_{3}$ pathways, ${ }^{19-21)}$ the events which follow an activation of CCK receptors in the CNS have not received much attention. It has also been shown in several cell lines, including $\mathrm{CHO}$ and $\mathrm{COS}-7$, that $\mathrm{CCK}$ receptors activate PLC, triggering an increase in inositol 1,4,5-trisphosphate $\left(\mathrm{IP}_{3}\right)$ production via a $\mathrm{G}_{\mathrm{q}}$ protein. $^{22-24)}$ In rat taste receptor cells, it has been reported that $\mathrm{CCK}$ produced $\mathrm{Ca}^{2+}$ elevations mediated via the activation of $\mathrm{CCK}_{1}$ receptors and intracellular $\mathrm{Ca}^{2+}$ store-dependent pathways. ${ }^{29}$ ) Therefore, it is highly possible that the signal of the liganded CCK receptor is mediated through heterotrimeric $\mathrm{G}$ proteins of the $\mathrm{G}_{\mathrm{q}}$ family to activate $\mathrm{PLC} / \mathrm{IP}_{3}$ pathways and release of intracellular $\mathrm{Ca}^{2+}$ and finally increases synaptic release of glutamate at presynaptic loci in the PAG. This fact is very important because it would provide a detailed cellular mechanism to support CCK-8S-mediated excitatory effects observed in vivo and in vitro electrophysiological recordings in this midbrain structure. ${ }^{11)}$

However, the present study clearly demonstrated that CCK-8S via the activation of $\mathrm{CCK}_{2}$ receptors induces an increase of $\left[\mathrm{Ca}^{2+}\right]_{\mathrm{i}}$ by influx of $\mathrm{Ca}^{2+}$ from the extracellular space but not from intracellular $\mathrm{Ca}^{2+}$ stores in acutely isolated PAG neurons. These observations are in agreement with other previous studies recorded in the CNS, but not in pancreatic cells and clonal cell lines, suggesting that it is highly possible that CCK-8S modulates intracellular $\mathrm{Ca}^{2+}$ differently in the CNS. Based on the present results, we suggest the detailed mechanism of CCK-8S-induced $\left[\mathrm{Ca}^{2+}\right]_{\mathrm{i}}$ increase in acutely isolated PAG neurons under the following circumstances. First, the present study showed that CCK-8S-induced $\left[\mathrm{Ca}^{2+}\right]_{\mathrm{i}}$ increase occurred not by direct modulation of $\mathrm{Ca}^{2+}$ channels because CCK-8S inhibited $\mathrm{Ca}^{2+}$ channels in the PAG. Although previous studies showing CCK-8S-induced $\left[\mathrm{Ca}^{2+}\right]_{\mathrm{i}}$ increase by influx of extracellular $\mathrm{Ca}^{2+}$ emphasized the involvement of L-type $\mathrm{Ca}^{2+}$ channels in myenteric neurons ${ }^{30)}$ or $\mathrm{N}$-type $\mathrm{Ca}^{2+}$ channels in striatal neurons, ${ }^{31)}$ voltage-dependent $\mathrm{Ca}^{2+}$ channels are not directly activated by application of CCK-8S. If the direct coupling of CCK receptors to voltage-dependent $\mathrm{Ca}^{2+}$ channels is essential, the increment of $\mathrm{Ca}^{2+}$ channels by $\mathrm{CCK}-8 \mathrm{~S}$ should be observed. However, the inhibition of $\mathrm{Ca}^{2+}$ channels by CCK-8S was noticed in the current study, and it is consistent with the previous reports recorded in the CNS such as hippocampus, motor, and sensory neurons. ${ }^{32-34)}$

Secondly, an inhibition of $\mathrm{K}^{+}$channels is a main cause for CCK-8S-induced $\left[\mathrm{Ca}^{2+}\right]_{\mathrm{i}}$ increase via the activation of $\mathrm{CCK}_{2}$ receptors. When simultaneous recording of $\mathrm{Ca}^{2+}$ imaging and whole-cell voltage-clamp on the same neuron was performed, CCK-8S-induced $\left[\mathrm{Ca}^{2+}\right]_{\mathrm{i}}$ increase was significantly decreased, and CCK-8S-induced inward current was reversed at $-95.7 \pm 3.2 \mathrm{mV}(n=6)$ with a decreased whole-cell slope conductance. This value of $E_{\text {rev }}$ is similar to the of $\mathrm{K}^{+}$ion predicted by the Nernst equation when an extracellular $\mathrm{K}^{+}$ concentration is $2.5 \mathrm{mM}$ (predicted $E_{\text {rev }}=-97.8 \mathrm{mV}$ ), suggesting CCK-8S-induced $\left[\mathrm{Ca}^{2+}\right]_{\mathrm{i}}$ increase is indirectly induced by a membrane depolarization due to an inhibition of $\mathrm{K}^{+}$channels. Attributed to prominent roles of $\mathrm{CCK}$ as a main neuropeptide modulating various neuronal functions such as satiety, nociception, and anxiety/panic behaviors, the nature of CCK-targeted ion channels has been examined in various neurons. For example, application of CCK has been 
known to produce a membrane depolarization or an inward current in the hippocampus, nucleus accumbens, and thalamus. ${ }^{32,35,36)}$ In most studies, including our previous one, ${ }^{25)}$ CCK-induced inward current was accompanied with a decreased membrane conductance and intersected near the $\mathrm{K}^{+}$ ion reversal potential. All together, these results suggest that CCK produced excitatory effects through an inhibition of $\mathrm{K}^{+}$ channels. Although further investigation is necessary to identify the types of $\mathrm{K}^{+}$channels affected by CCK and its detailed mechanism for CCK-induced $\left[\mathrm{Ca}^{2+}\right]_{\mathrm{i}}$ increase, the evidence presented here expands our understanding of the CCKmediated excitatory action in the brain including the PAG.

Acknowledgements The authors extend their appreciation to ML Laboratories (Warrington, U.K.) for providing L364718 and L-365260. This work was supported by KIST Core-Competence Program and Brain Research Center of the 21st Century Frontier Research Program (M103KV01000606K2201-00610) from MOST, the Republic of Korea.

\section{REFERENCES}

1) Bandler R., Shipley M. T., Trends Neurosci., 17, 379-389 (1994).

2) Carrive P., Bandler R., Dampney R. A., Brain Res., 460, 339-345 (1988).

3) Basbaum A. I., Fields H. L., Annu. Rev. Neurosci., 7, 309-338 (1984).

4) Ossipov M. H., Lai J., Malan T. P., Jr., Porreca F., Ann. N.Y. Acad. Sci., 909, 12-24 (2000).

5) Behbehani M. M., Prog. Neurobiol., 46, 575-605 (1995).

6) Fanselow M. S., "The Midbrain Periaqueductal Gray Matter: Functional, Anatomical, and Neurochemical Organization," ed. by Depaulis A., Bandler R., Plenum Press, New York, 1991, pp. 151-174.

7) Benedetti F., News Physiol. Sci., 12, 263-268 (1997).

8) Noble F., Roques B. P., Neuropeptides, 36, 157-170 (2002).

9) Noble F., Wank S. A., Crawley J. N., Bradwejn J., Seroogy K. B., Hamon M., Roques B. P., Pharmacol. Rev., 51, 745-781 (1999).

10) De Belleroche J., Bandopadhyay R., King A., Malcolm A. D., O'Brien K., Premi B. P., Rashid A., Neuropeptides, 15, 201-212 (1990).

11) Liu H., Chandler S., Beitz A. J., Shipley M. T., Behbehani M. M.,
Brain Res., 642, 83-94 (1994).

12) Li Y., Han J. S., Brain Res., 480, 105-110 (1989).

13) Watkins L. R., Kinscheck I. B., Mayer D. J., Science, 224, 395-396 (1984).

14) Watkins L. R., Kinscheck I. B., Mayer D. J., Brain Res., 327, 169180 (1985).

15) Tortorici V., Nogueira L., Salas R., Vanegas H., Pain, 102, 9-16 (2003).

16) Netto C. F., Guimaraes F. S., Neuropsychopharmacology, 29, 101107 (2004)

17) Kopin A. S., Lee Y. M., McBride E. W., Miller L. J., Lu M., Lin H. Y., Kolakowski L. F., Jr., Beinborn M., Proc. Natl. Acad. Sci. U.S.A., 89, 3605-3609 (1992)

18) Wank S. A., Am. J. Physiol., 269, G628-G646 (1995).

19) Williams J. A., Sans M. D., Tashiro M., Schafer C., Bragado M. J., Dabrowski A., Pharmacol. Toxicol., 91, 297-303 (2002).

20) Daulhac L., Kowalski-Chauvel A., Pradayrol L., Vaysse N., Seva C., Biochem. J., 325, 383-389 (1997).

21) Seva C., Scemama J. L., Pradayrol L., Sarfati P. D., Vaysse N., Regul. Pept., 52, 31-38 (1994)

22) Jagerschmidt A., Guillaume N., Goudreau N., Maigret B., Roques B. P., Mol. Pharmacol., 48, 783-789 (1995).

23) Dickenson J. M., Hill S. J., Eur. J. Pharmacol., 302, 141-151 (1996).

24) Wang H. L., Br. J. Pharmacol., 121, 310 -316 (1997).

25) Yang Y. M., Chung J. M., Rhim H., Life Sci., 79, 1702-1711 (2006).

26) Hahm E. T., Lee J. J., Min B. I., Cho Y. W., Neurosci. Res., 50, 343354 (2004).

27) Clapham D. E., Nature (London), 375, 634-635 (1995).

28) Miller R. J., Science, 235, 46-52 (1987).

29) Herness S., Zhao F. L., Lu S. G., Kaya N., Shen T., J. Neurosci., 22, 10018 - 10029 (2002).

30) Zhang W., Segura B. J., Mulholland M. W., Peptides, 23, 1793-1801 (2002).

31) Miyoshi R., Kito S., Nomoto T., Neuropeptides, 18, 115-119 (1991).

32) Shinohara S., Kawasaki K., Neuroscience, 78, 1005-1016 (1997).

33) Xu T., Liu N. J., Li C. Q., Shangguan Y., Yu Y. X., Kang H. G., Han J. S., Brain Res., 730, 207-211 (1996).

34) Bayliss D. A., Umemiya M., Berger A. J., J. Physiol., 485, 635-647 (1995).

35) Cox C. L., Huguenard J. R., Prince D. A., J. Neurophysiol., 74, 9901000 (1995).

36) Kombian S. B., Ananthalakshmi K. V., Parvathy S. S., Matowe W. C., J. Physiol., 555, 71—84 (2004). 